\title{
Parasitism by Amblyomma humerale (Acari: Ixodidae) on Chelonoidis denticulatus (Testudines: Testudinidae) in the Atlantic Forest
}

\author{
Parasitismo de Chelonoidis denticulatus (Testudines: Testudinidae) por \\ Amblyomma humerale (Acari: Ixodidae) na Mata Atlântica \\ Ygor Machado'; Igor Cunha Lima Acosta2; Thiago Fernandes Martins²; Ana Carolina Srbek-Araujo ${ }^{1,3,4^{*}}$ (D) \\ ${ }^{1}$ Programa de Pós-graduação em Ciência Animal, Universidade Vila Velha - UVV, Vila Velha, ES, Brasil \\ ${ }^{2}$ Departamento de Medicina Veterinária Preventiva e Saúde Animal, Faculdade de Medicina Veterinária e Zootecnia, Universidade de \\ São Paulo - USP, São Paulo, SP, Brasil \\ ${ }^{3}$ Programa de Pós-graduação em Ecologia de Ecossistemas, Universidade Vila Velha - UVV, Vila Velha, ES, Brasil \\ ${ }^{4}$ Instituto SerraDiCal de Pesquisa e Conservação, Belo Horizonte, MG, Brasil
}

How to cite: Machado Y, Acosta ICL, Martins TF, Srbek-Araujo AC. Parasitism by Amblyomma humerale (Acari: Ixodidae) on Chelonoidis denticulatus (Testudines: Testudinidae) in the Atlantic Forest. Braz J Vet Parasitol 2021; 30(3): e002921. https://doi. org/10.1590/S1984-29612021044

\begin{abstract}
The present study reports on patterns of parasitism by Amblyomma humerale on yellow-footed tortoise, Chelonoidis denticulatus, in the Atlantic Forest of southeastern Brazil. The tortoises were sampled occasionally, from July 2005 to January 2020. We collected 81 adult ticks from seven tortoises (mean $=11.57 \pm 6.90$ ticks/host), of which 72 were males (88.9\%) and nine females (11.1\%), resulting in an 8:1 sex ratio (males:females). Males were found in clusters, attached to the carapace. Females occurred mainly isolated, attached to coriaceous integumental areas $(n=7 ; 77.8 \%)$, especially the engorged females (100\%). We suggest that the difference between attachment sites is a strategy used by fertilized females to avoid mechanical removal from their host through friction with elements of the environment. Because they undergo a considerable increase of volume when engorged, they move to more sheltered places on their host's surface. The parasitism patterns by A. humerale on C. denticulatus were compatible with those observed in the Amazon region and in the Cerrado-Amazonia transition. The present work provides information about the life history and host-parasite interface of the two species and contributes to understanding the parasitism patterns by A. humerale on C. denticulatus in the Atlantic Forest of southeastern Brazil.
\end{abstract}

Keywords: Ectoparasite, host-parasite interaction, infestation, tick, yellow-footed tortoise.

\section{Resumo}

O presente estudo relata os padrões de parasitismo de Amblyomma humerale em jabuti-tinga, Chelonoidis denticulatus, na Mata Atlântica do Sudeste do Brasil. Os jabutis foram amostrados de forma ocasional, entre julho de 2005 e janeiro de 2020. Foram amostrados sete jabutis e coletados 81 carrapatos adultos (media $=11,57 \pm 6,90$ carrapatos/hospedeiro), sendo 72 machos ( $88,9 \%$ ) e nove fêmeas (11,1\%), resultando em uma razão sexual de 8:1 (machos:fêmeas). Os machos encontravam-se agrupados e aderidos à carapaça. As fêmeas ocorreram principalmente isoladas e fixadas a áreas de tegumento coriáceo $(n=7 ; 77,8 \%)$, especialmente as fêmeas ingurgitadas (100\%). Sugere-se que a diferença entre os locais de fixação seja uma estratégia das fêmeas fecundadas, para evitar a remoção mecânica por atrito com o ambiente, uma vez que aumentam consideravelmente seu volume quando ingurgitadas, deslocando-se para locais mais abrigados na superfície do hospedeiro. Os padrões de parasitismo de C. denticulatus por A. humerale foram compatíveis com aqueles observados na Amazônia e na transição Amazônia-Cerrado. O presente trabalho contribui com informações acerca da história de vida e da relação parasito-hospedeiro entre as duas espécies, contribuindo para o entendimento dos padrões de parasitismo de A. humerale em C. denticulatus na Mata Atlântica do sudeste do Brasil.

Palavras-chave: Ectoparasito, interação parasito-hospedeiro, infestação, carrapato, jabuti-tinga. 
Ticks are of great importance in epidemiological studies on diseases due to the deleterious effects that they cause, such as blood spoliation and transmission of infectious agents to hosts. These hosts can include domestic and wild animals, as well as humans (Estrada-Peña et al., 2004; Guglielmone et al., 2014; Witter et al., 2016).

Worldwide, 136 species of the genus Amblyomma Koch, 1844 have been described, including 46 that are exclusive to the Neotropical region (Guglielmone et al., 2014). In Brazil, 33 species of this genus have been recorded (Martins et al., 2019). The tick Amblyomma humerale Koch, 1844 is considered to be an endemic species in South America, and its presence has been reported in Bolivia, Brazil, Colombia, Ecuador, French Guiana, Guyana, Suriname, Trinidad and Tobago and Venezuela (Labruna et al., 2002a; Morais et al., 2017). In Brazil, this species can be found in the Amazon region (Labruna et al., 2002a, 2004; Gianizella et al., 2018), transition zone between the Cerrado (the Brazilian savanna) and Amazon rainforest (Morais et al., 2017) and Atlantic Forest (Sinkoc \& Brum, 1997; Ogrzewalska et al., 2007).

Parasitism by adult $A$. humerale has commonly been associated with terrestrial turtles (Testudines, Testudinidae), such as Chelonoidis denticulatus (Linnaeus, 1766) (yellow-footed tortoise) and Chelonoidis carbonarius (Spix, 1824) (red-footed tortoise) (Labruna et al., 2002a; Ogrzewalska et al., 2007; Guglielmone et al., 2014; Morais et al., 2017; Martins et al., 2020). Other reports have described parasitism of adult $A$. humerale on the toad Rhinella arenarum (Hensel, 1867) (previously Bufo arenarum - Anura, Bufonidae; Sinkoc \& Brum, 1997) and, under laboratory conditions, on Trachemys scripta (Wied-Neuwied, 1839) (red-eared slider - Testudines, Emydidae; Martins et al., 2020). Immature stages of the parasite have already been found on caimans, lizards and snakes (Labruna et al., 2002a; Martins et al., 2020), wild mammals (Witter et al., 2016; Fuverki et al., 2021) and birds (Ogrzewalska et al., 2010; Souza et al., 2020). Although reports on the usual hosts of $A$. humerale in the different biomes in which it occurs have been produced, details of parasitism patterns exhibited by this species have been described only for the state of Rondônia, in the Amazon region (Labruna et al., 2002a), and in the central-western portion of Mato Grosso state, in the CerradoAmazonia transition (Morais et al., 2017).

The aim of the present study was to report on the parasitism patterns shown by A. humerale on C. denticulatus in the Atlantic Forest of southeastern Brazil.

From July 2005 to January 2020, specimens of C. denticulatus were occasionally recorded when spotted on unpaved roads inside the Vale Natural Reserve (Reserva Natural Vale, RNV; -19.0211S, -40.0717W and -19.2536S, -39.8686W). This protected area is located in the municipality of Linhares, in the northern region of the state of Espírito Santo, southeastern Brazil. The tortoises were collected manually and inspected for ticks. Male ticks and engorged and non-engorged female ticks were counted separately, and the locations of the parasites were recorded. The tortoises and their parasites were photographed, and the ticks were then collected from them (SISBIO 21990). The ticks collected were immediately stored in plastic bottles containing $70 \%$ ethanol for subsequent identification. Identification was done through observation of morphological characteristics, as described in the specialized literature (Guimarães et al., 2001; Barros-Battesti et al., 2006), with the aid of a stereomicroscope StemiTM DV4 (Carl ZeissTM, Jena, Germany). A voucher specimen was deposited in the tick collection "Coleção Nacional de Carrapatos Danilo Gonçalves Saraiva" (CNC), at the School of Veterinary Medicine of the University of São Paulo, with voucher number CNC-4086.

To assess parasitism patterns, the mean, standard deviation and amplitude of the infestation rates of male ticks and female (engorged and non-engorged) ticks were calculated, along with the sex ratio of the parasites. Parasite attachment sites were also characterized.

We recorded 81 adult ticks of the species $A$. humerale that were found on seven specimens of $C$. denticulatus (Table 1). The mean infestation rate was $11.57 \pm 6.90$ (minimum $=1$; maximum $=22$ ) ticks per specimen. Among the ticks recorded, 72 were males (88.9\%) and nine females (11.1\%), resulting in an infestation sex ratio of 8:1 (males:females). Male ticks had a mean infestation rate of $10.29 \pm 6.92$ (minimum $=0$; maximum $=21$ ) ticks per host. Only one tortoise did not have any male ticks on it. The mean infestation rate of $A$. humerale females was $1.29 \pm 0.95$ (minimum = 0; maximum = 3) ticks per tortoise. Similar to what was observed for male ticks, only one host did not have any female ticks on it. Almost all the male ticks were found clustered $(n=71 ; 98.6 \%)$ and were attached to the scutes of the carapace or to the intersections of the scutes (Figure 1). Females occurred mainly in isolation ( $n=8 ; 88.9 \%)$ and parasitism was observed mainly in regions of coriaceous integument $(n=7 ; 77.8 \%)$, such as the neck region (ventral and dorsal areas; Figure 1), pelvic limbs (close to the carapace) and base of the tail. In only two cases, the females were attached to the scutes of the carapace (22.2\%). Out of the nine females collected, five were engorged (55.6\%). The two females attached to the carapace were not engorged. 
Table 1. Number of adult individuals of Amblyomma humerale parasitizing Chelonoidis denticulatus, according to the recorded date and the sex of the ticks, in the Atlantic Forest of southeastern Brazil (from July 2005 to January 2020).

\begin{tabular}{cccc}
\hline Sampling date & Number of males & Number of females & Total \\
\hline Jul 19, 2005 & 15 & 1 & 16 \\
Mar 8, 2014 & 9 & 3 & 12 \\
Jan 28, 2016a & 7 & 0 & 7 \\
Jan 28, 2016b & 14 & 1 & 15 \\
Apr 14, 2018 & 6 & 2 & 8 \\
Sep 27, 2019 & 0 & 1 & 1 \\
Jan 15, 2020 & 21 & 1 & $\mathbf{2}$ \\
Total & $\mathbf{7 2}$ & $\mathbf{9}$ & $\mathbf{8 1}$ \\
\hline
\end{tabular}

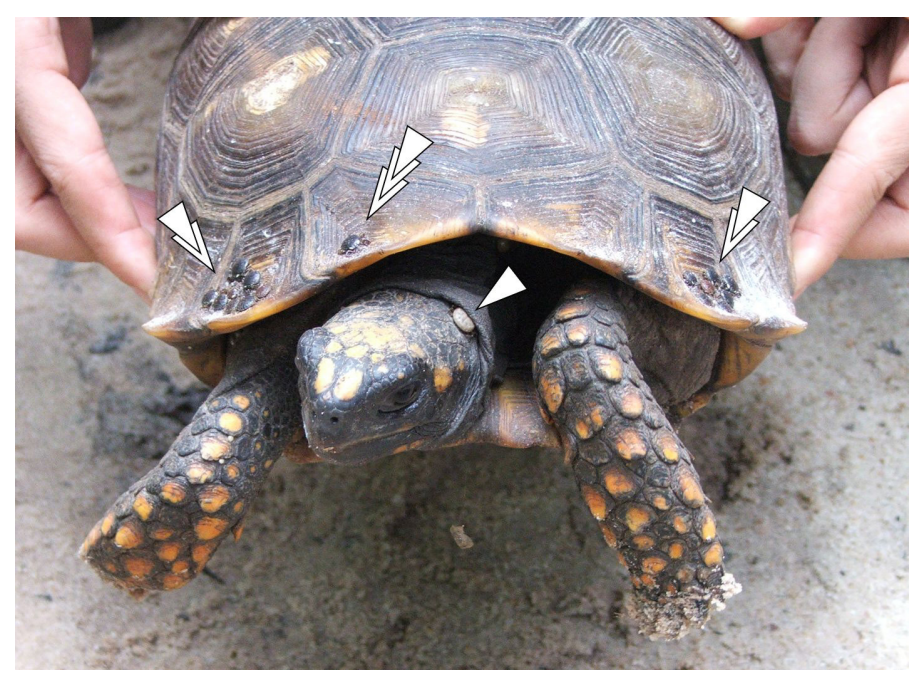

Figure 1. Amblyomma humerale parasitizing Chelonoidis denticulatus in the Atlantic Forest of southeastern Brazil: engorged female attached to coriaceous integument of the neck (arrow), clustered males on the scutes of the carapace (double arrow) and isolated male (triple arrow).

Parasitism of C. denticulatus by A. humerale had previously been reported in RNV (Ogrzewalska et al., 2007). Another previous record in Espírito Santo (municipality of Pinheiros, in the extreme north of the state) included reporting of Rickettsia amblyommatis (published as Rickettsia amblyommii) in this tick species for the first time (Acosta et al., 2016). In the previous study in RNV, 43 adult ticks ( 35 males and eight females) were found on two tortoises, with an average of 21.50 ticks per specimen (Ogrzewalska et al., 2007). Unlike the work of Ogrzewalska et al. (2007), the average infestation rate observed in the present study was almost 1.9 times lower. In the previous work, the collections were carried out at the beginning of April 2006 (sampling at a single time), while the collections carried out in the present work occurred at different times and seasons. However, it is worth mentioning that a tortoise that was collected in April of one of the years of our study was infested with eight ticks, and that this rate was also lower than what was found by Ogrzewalska et al. (2007). It has been reported that adult ticks of the genus Amblyomma sp. have a certain seasonality regarding the degree of activity in the environment and infestation of their hosts, with the peak of infestation between August and March, mainly in the spring and summer seasons (Oliveira et al., 2000; Labruna et al., 2002b; Labruna et al., 2003; Luz et al., 2015), noting also that the peak of infestation may extend until April (Morais et al., 2017). The proximity of the sampling reported by Ogrzewalska et al. (2007) to the summer period may have been the explanation for the higher mean infestation rate that they found. In the present sampling, the highest number of ticks was recorded in January, at the beginning of summer, and the lowest number in September, which corresponds to the end of winter.

Microclimatic factors from the habitat may also interfere with tick infestations. Torres et al. (2018), in the state of Pará (Amazon region), observed greater infestation by ticks of the genus Amblyomma sp. on amphibians and reptiles collected in open areas, such as pastures and savannas, than in closed wooded areas. Open areas have 
higher incidence of solar radiation and therefore are hotter, which provides a favorable scenario for the activity and development of parasites (Labruna et al., 2003). In the present study, the sampling took place in forested areas, which may explain why the specimens were less infested. Unfortunately, in Ogrzewalska et al. (2007), there is no detailed information about the areas where the tortoises were collected, for better comparison among the studies.

Overall, parasitism rates among male ticks were higher, with the exception of the specimen that only had one engorged female. Thus, males were predominant in the sex ratio of the present study. Higher occurrence of A. humerale males parasitizing C. denticulatus in the Amazon region was noticed by Labruna et al. (2002a), in the state of Rondônia, with a 10.3:1 ratio (male: female); and by Ogrzewalska et al. (2007) in RNV, although the proportion of males was 1.8 times lower than what was recorded in the present study (sex ratio of infestation $=4.4: 1$ ).

The longer attachment time of male ticks on parasitized organisms may explain the greater presence of males of this genus on hosts, compared with female ticks. It should be emphasized that the ticks remain attached during the period in which they feed and mate (Anderson \& Magnarelli, 2008), and that females leave their hosts to lay their eggs. Under laboratory conditions, A. humerale females were found to remain attached to red-eared sliders for an average of 24 days ( \pm 5.8; Martins et al., 2020). There is a lack of studies on the duration of attachment of A. humerale males on their hosts, but under experimental conditions, Amblyomma sculptum Berlese, 1888 (published as Amblyomma cajennense) male ticks remained attached to their hosts for up to 86 days (Pinter et al., 2002). Similar results were observed by Labruna et al. (2002b) in a study on A. sculptum (published as A. cajennense) parasitizing grazing horses in the state of São Paulo.

Overall, the males in the present study were observed forming clusters, which on one occasion also had the presence of a non-engorged female. On another occasion, a non-engorged female was adjacent to the male group, but without contact with other specimens (a few centimeters apart from them). This may have been due to the fact that male ticks secrete pheromones that stimulate aggregation of other males, females and nymphs around them (Rechav et al., 1977), thus inducing the formation of clusters.

A difference between the ticks' attachment sites was noticed. Females were more commonly found attached to soft tissues, especially engorged females, differently from males, which were observed adhering to the carapace. This pattern had already been reported previously, although no justification for such behavior was presented (Labruna et al., 2002a; Morais et al., 2017). We suggest that after fertilization, the females move to more sheltered places on the surface of the host's body. As they become engorged, they increase their volume considerably, and become more susceptible to mechanical removal when the tortoise moves against vegetation or the substrate. Therefore, the parts of the leathery tissue near the edge of the carapace and areas that could become hidden inside the carapace when the animal retracts are more protected, unlike the surface of the carapace, which is constantly subject to friction with the environment.

The present study demonstrated that the parasitism patterns shown by A. humerale on C. denticulatus in the Atlantic Forest were compatible with those observed in the Amazon region and in the Cerrado-Amazonia transition. This study contributes new information about the life history of these two species and their host-parasite interface. Development of further studies describing the feeding behavior of males and females of $A$. humerale is recommended, which may provide detailed information about the biology of this species and the peculiarities of its interaction with its hosts under natural conditions.

\section{Acknowledgements}

We would like to thank Vale S.A. and Instituto Ambiental Vale for its support during field activities. Y. Machado thanks the Fundação de Amparo à Pesquisa e Inovação do Espírito Santo (FAPES) for the postgraduate scholarship. A.C. Srbek-Araujo thanks FAPES (grants 607/2015 and 510/2016) for sponsoring the research activities of the Laboratório de Ecologia e Conservação de Biodiversidade (LECBio - UVV).

\section{References}

Acosta ICL, Martins TF, Marcili A, Soares HS, Krawczak FS, Vieira FT, et al. Ticks (Acari: Ixodidae, Argasidae) from humans, domestic and wild animals in the state of Espírito Santo, Brazil, with notes on rickettsial infection. Vet Parasitol Reg Stud Reports 2016; 3-4: 66-69. http://dx.doi.org/10.1016/j.vprsr.2016.08.001. PMid:31014503.

Anderson JF, Magnarelli LA. Biology of ticks. Infect Dis Clin North Am 2008; 22(2): 195-215, v. http://dx.doi.org/10.1016/j. idc.2007.12.006. PMid:18452797. 
Barros-Battesti DMB, Arzua M, Bechara GH. Carrapatos de importância medico-veterinária da Região Neotropical: um guia ilustrado para identificação de espécies. São Paulo: Butantan; 2006.

Estrada-Peña A, Guglielmone AA, Mangold AJ. The distribution and ecological 'preferences' of the tick Amblyomma cajennense (Acari: Ixodidae), an ectoparasite of humans and other mammals in the Americas. Ann Trop Med Parasitol 2004; 98(3): $283-292$. http://dx.doi.org/10.1179/000349804225003316. PMid:15119974.

Fuverki RBN, Martins AL, Martins TF, Muraro LS, Souza AO, Barbosa JL, et al. Parasitism of a capybara (Hydrochoerus hydrochaeris) by Amblyomma nodosum Neumann, 1899 and Amblyomma humerale Koch, 1844 in an Amazon forest area, Rondônia, Brazil. Arq Bras Med Vet Zootec 2021; 73(1): 265-269. http://dx.doi.org/10.1590/1678-4162-12112.

Gianizella SL, Martins TF, Onofrio VC, Aguiar NO, Gravena W, do Nascimento CAR, et al. Ticks (Acari: Ixodidae) of the State of Amazonas, Brazil. Exp App/ Acarol 2018; 74(2): 177-183. http://dx.doi.org/10.1007/s10493-018-0221-7. PMid:29383533.

Guglielmone AA, Robbins RG, Apanaskevich DA, Petney TN, Estrada-Peña A, Horak IG. The hard ticks of the World (Acari: Ixodida: Ixodidae). Netherlands: Springer; 2014. http://dx.doi.org/10.1007/978-94-007-7497-1

Guimarães JH, Tucci EC, Barros-Battesti DM. Ectoparasitos de importância veterinária. São Paulo: Plêide/Fapesp; 2001.

Labruna MB, Amaku M, Metzner JA, Pinter A, Ferreira F. Larval behavioral diapause regulates life cycle of Amblyomma cajennense (Acari: Ixodidae) in Southeast Brazil. J Med Entomol 2003; 40(2): 170-178. http://dx.doi.org/10.1603/0022-2585-40.2.170. PMid:12693845.

Labruna MB, Camargo LMA, Terrassini FA, Schumaker TTS, Camargo EP. Notes on parasitism by Amblyomma humerale (Acari: Ixodidae) in the State of Rondônia, Western Amazon, Brazil. J Med Entomol 2002a; 39(6): 814-817. http://dx.doi.org/10.1603/0022 2585-39.6.814. PMid:12495177.

Labruna MB, Kasai N, Ferreira F, Faccini JLH, Gennari SM. Seasonal dynamics of ticks (Acari: Ixodidae) on horses in the State of São Paulo, Brazil. Vet Parasitol 2002b; 105(1): 65-77. http://dx.doi.org/10.1016/S0304-4017(01)00649-5. PMid:11879967.

Labruna MB, Whitworth T, Bouyer DH, McBride J, Camargo LMA, Camargo EP, et al. Rickettsia bellii and Rickettsia amblyommii in Amblyomma ticks from the State of Rondônia, Western Amazon, Brazil. J Med Entomol 2004; 41(6): 1073-1081. http://dx.doi. org/10.1603/0022-2585-41.6.1073. PMid:15605647.

Luz HR, Faccini JLH, Silva HR. Patterns of parasitism by Amblyomma rotundatum (Ixodidae) on Rhinella schneideri (Bufonidae) in islands of São Francisco River, Minas Gerais, Brazil. Pesq Vet Bras 2015; 35(6): 579-582. http://dx.doi.org/10.1590/S0100736X2015000600016.

Martins TF, Luz HR, Muñoz-Leal S, Ramirez DG, Milanelo L, Marques S, et al. A new species of Amblyomma (Acari: Ixodidae) associated with monkeys and passerines of the Atlantic rainforest biome, Southeastern Brazil. Ticks Tick Borne Dis 2019; 10(6): 101259. http://dx.doi.org/10.1016/j.ttbdis.2019.07.003. PMid:31320285.

Martins TF, Teixeira RHF, Benatti HR, Minervino AHH, Soares HS, Soares JF, et al. Life cycle of the tick Amblyomma humerale (Parasitiformes: Ixodida) in the Laboratory. Int J Acaro/ 2020; 46(5): 351-356. http://dx.doi.org/10.1080/01647954.2020.1802510.

Morais DH, Carvalho VT, Bonora L, Kawashita-Ribeiro RA, Strüssmann C. Patterns of parasitism by Amblyomma humerale (Acari: Ixodidae) on Chelonoidis denticulata (Testudines: Testudinidae) in the Brazilian Midwest. Herpetol Rev 2017; 48(2): $316-319$.

Ogrzewalska M, Uezu A, Ferreira F, Labruna MB. Carrapatos (Acari: Ixodidae) capturados na Reserva Natural da Vale Do Rio Doce, Linhares, Espírito Santo. Rev Bras Parasitol Vet 2007; 16(3): 177-179. http://dx.doi.org/10.1590/S1984-29612007000300014. PMid:18078608.

Ogrzewalska M, Uezu A, Labruna MB. Ticks (Acari: Ixodidae) infesting wild birds in the Eastern Amazon, Northern Brazil, with notes on rickettsial infection in ticks. Parasitol Res 2010; 106(4): 809-816. http://dx.doi.org/10.1007/s00436-010-1733-1. PMid:20140452.

Oliveira PR, Borges LMF, Lopes CML, Leite RC. Population dynamics of the free-living stages of Amblyomma cajennense (Fabricius, 1787) (Acari: Ixodidae) on pastures of Pedro Leopoldo, Minas Gerais State, Brazil. Vet Parasitol 2000; 92(4): 295-301. http://dx.doi. org/10.1016/S0304-4017(00)00322-8. PMid:10996741.

Pinter A, Labruna MB, Faccini JLH. The sex ratio of Amblyomma cajennense (Acari: Ixodidae) with notes on the male feeding periods in the laboratory. Vet Parasito/ 2002; 105(1): 79-88. http://dx.doi.org/10.1016/S0304-4017(01)00650-1. PMid:11879968.

Rechav Y, Parolis H, Whitehead GB, Knight MM. Evidence for an assembly pheromone(s) produced by males of the bont tick, Amblyomma hebraeum (Acarina: ixodidae). J Med Entomol 1977; 14(1): 71-78. http://dx.doi.org/10.1093/jmedent/14.1.71. PMid:903938.

Sinkoc AL, Brum JGW. Ocorrência de Amblyomma fuscum Neumann, 1899 e Amblyomma humerale Koch, 1844 (Acari: Ixodidae) em Bufo arenalis no Estado de São Paulo, Brasil. Cienc Rural 1997; 27(2): 339-340. http://dx.doi.org/10.1590/S0103-84781997000200029.

Souza VL, Martins TF, Guilherme E, Santos FGA. New records of ticks (Acari: Ixodidae) infesting wild birds in a forest fragment in Acre, Brazilian Amazon. Semina: Ciênc Agrár 2020; 41(5): 2163-2170. http://dx.doi.org/10.5433/1679-0359.2020v41 n5supl1 p2163. 
Torres AC, Minervino AHH, Santos APJr, Sarturi C, Martins TF, Vale WG, et al. Amblyomma ticks infesting amphibians and squamata reptiles from the Lower Amazon region, Brazil. Exp Appl Acarol 2018; 75(4): 399-407. http://dx.doi.org/10.1007/s10493-018-02774. PMid:30088214.

Witter R, Martins TF, Campos AK, Melo ALT, Corrêa SHR, Morgado TO, et al. Rickettsial infection in ticks (Acari: Ixodidae) of wild animals in Midwestern Brazil. Ticks Tick Borne Dis 2016; 7(3): 415-423. http://dx.doi.org/10.1016/j.ttbdis.2015.12.019. PMid:26775021. 